MIRJANA VOJVODA

Institute of Archaeology

Belgrade, Serbia

E-mail: mirjana.vojvoda@gmail.com

ILIJA MIKIĆ

Institute of Archaeology

Belgrade, Serbia

E-mail: mikicilija82@gmail.com
Received: October $02^{\text {nd }} 2020$

Accepted: December $10^{\text {th }} 2020$

Original research article

904:737.1.032(37)"02"

904:726.821"652"(497.11)

COBISS.SR-ID 29129481

https://doi.org/10.18485/arhe_apn.2020.16.8

\title{
DISTRIBUTION RATIO OF ISSUES FROM THE MINTS OF VIMINACIUM AND DACIA: THE EXAMPLE OF THE SOUTHERN NECROPOLES OF VIMINACIUM
}

\begin{abstract}
Data on coin finds from the southern necropoles of Viminacium represent precious material for analysing the monetary circulation of provincial mints of Viminacium and Dacia, in the territory of Moesia Superior. A large sample of processed coins (6233), originating from archaeological research activities on these necropoles, provides the possibility for various kinds of comparisons. As shown by comparative analyses of monetary finds from these two mints on the territory of Moesia Superior and Dacia, issues from Viminacium had the goal of a wider circulation range, while issues from the province of Dacia, it would seem, were minted only for the needs of that particular province. In any case, production of both mints from the Balkans, in Dacia and Viminacium, represented a manner of handling the monetary crisis in the middle of the 3rd century and providing the money necessary for the army.
\end{abstract}

\section{KEYWORDS: ROMAN EMPIRE, PROVINCIAL MINTS, VIMINACIUM, DACIA.}

A lack of imperial bronze coinage in circulation in the Danube Valley and the Balkans provinces was especially prominent at the beginning of the 3rd century and probably represented the main reason for opening a provincial coins mint in Viminacium in 239, and then another one in Dacia, in 246. This lack of small bronze coins was especially notable in Moesia Superior (Upper Moesia) and both Pannonias (Борић-Брешковић 1976: 8, ref. 2; Црнобрња 1993: 17-19; Găzdac and Alföldy-Găzdac 2008: 136, ref. 14; Војвода и Петровић 2011: 288-289; Војвода и Јесретић 2012: 121-122; Војвода 2013: 159-160; Vojvoda i Mrđić 2015: 14-17, ref. 10-13; Vojvoda i Mrđić 2017: 15-16; Borić-Brešković and Vojvoda 2018: 74, ref. 3; Vojvoda and Crnobrnja 2018: 133, ref. 10). The provincial coins mint in Viminacium was opened in October 239, which was also the starting year of the provincial era (AN I - AN XVI). ${ }^{1}$ It was active for 16 years, from 239/240 up to $254 / 255$, with two intermission periods, in 248/249 (AN X) and in 253/254 (AN XV). ${ }^{2}$ Viminacium obtained the right to mint provincial coins at the same time as it got the status of a colony, at the beginning of the reign of Gordian III. ${ }^{3}$ On

1 The period between October 19th and October 21st 239 is taken as the beginning of the monetary era of Viminacium; cf. Dušanić 1976: 58.

2 It is most likely that the interruption in the work during AN X was caused by Pacatianus' usurpation, who was minting antoniniani in Viminacium at that time, in order to pay the army. Similarly, the interruption during AN XV in the time of Valerian I is interpreted by the minting of antoniniani for military needs in the war with the Sassanians; cf. Pegan 1984: 213; Vasić 2012: 14-15; Găzdac and Alföldy-Găzdac 2008: 141, ref. 43-46.

3 A secondary imperial mint was also operating in Viminacium, opened at a later time, during the reign of Philip I; cf. Kondić 1969: 47-65; Vasić 2005: 19; Vasić 2012: 39-41 
the other hand, it would seem that the beginning of minting in Dacia was linked to the sojourn of Philip I in this province, and operations against the Carpi. ${ }^{4}$ The mint in Dacia produced coin issues during a period of ten years, with the mark of the local era from AN I - X (246/247-254/256). ${ }^{5}$

Data on coinage findings from the southern necropoles of Viminacium represent precious material for an analysis of monetary circulation in the territory of Moesia Superior in the period 192-238 $\mathrm{AD}$, i.e. the period before the opening of the provincial coins mint in Viminacium, and then the subsequent mint in Dacia. A large sample of processed coins (6233) originating from archaeological research activities on these necropoles provides the possibility for various kinds of comparisons. Out of the total number of registered examples of imperial and provincial coins (6228), ${ }^{6} 5128$ pieces belong to the imperial type $(82.33 \%)$, while 1100 pieces belong to the provincial type (17.67\%). If we exclude the coins from the 4th and the 5th century (Pećine -544 pieces and Više Grobalja - 42 pieces), we get the following ratio for the imperial and provincial coins during the first three centuries: $80.50 \%$ (4542 pieces) versus $19.50 \%$ (1100 pieces).

The analysis of monetary circulation in this period (192-238), on the basis of the sample from Viminacium, has shown a domination of issues

with references therein.

4 Găzdac, Alföldy-Găzdac 2008: 140. According to Fitz, these events were also the cause for a secondary imperial mint to be opened in Viminacium; cf. Fitz 1978: 642.

5 The period of July-August 246 is taken as the beginning of the Dacian monetary era. Thus, the monetary eras of Viminacium and Dacia mostly overlap, with the difference of roughly three months; cf. Vasić 2012: 15.

6 The total number of processed examples of coins originating from the necropoles of Više Grobalja and Pećine is 6233. The total of 6228 comprehends examples of imperial (1st5 th century) and provincial mints (1st-3rd century). The five examples which haven't been included in our analysis belong to Republican mints (2), Greek mints from the 2nd century BC (1) and imitations (2); cf. Vojvoda i Mrđić 2015: 10, Table 1, ref. 6; Vojvoda i Mrđić 2017: 10, Table 1, ref. 5.

7 This calculation also includes the coins from the 4th and the 5th century, originating from the most recent of the three necropoles from the site of Pećine (Vojvoda i Mrđić 2017: 14-16, ref. 16, Table 4). of provincial coins compared to the imperial ones (65\% to 35\%) (Borić-Brešković and Vojvoda 2018: 76-77, Table 1, Graph 1). By observing just the provincial mints, it has been noted that issues from the Stobi mint prevailed from the reign of Septimius Severus up to the reign of Elagabalus, while issues from the Bithynian mint in Nicaea can almost exclusively be registered during the time of Alexander Severus. Other mints from Asia Minor and Thrace are present in smaller percentages (Borić-Brešković and Vojvoda 2018: 76). From the opening of the provincial mint in Viminacium, and its issues entering circulation, right until it was closed (between 238 and 255), a lack of imperial issues became even more prominent (they are present in only 11\%) (Borić-Brešković and Vojvoda 2018: 78, Graph 2). When it comes to provincial issues, the mint from Viminacium dominates with ca $50 \%$, followed by the mint from Nicaea with $42 \%$, while issues from the mints in Dacia and Thrace are present with only $2.27 \%$ each.

Finds of coinage from the province of Dacia, produced in considerably smaller numbers than coinage from the mint of Viminacium, had a certain role in the monetary circulation in the area of Moesia Superior. Thus, 155 examples of coins from the southern necropoles of Viminacium originated from the mint of Viminacium (93.40\%) and 11 from the mint in Dacia (6.60\%). Coin hoards also provide possibilities of gaining insight into the monetary flows of a given period. In 10 hoards on the territory of today's Serbia, coinage from both of these provincial mints are present, with a similar ratio (on average 8.70\%): Bošnjane 61:2; Brežane 25:2; Bujkovac 120:2; Vlajića Brdo I 101:14; vicinity of Vranje 19:3; Popovac 15:2; vicinity of Ćuprija 73:7; Izvore 26:2; Vrkašice 106:10; and Sremska Mitrovica 128:8.

8 Bošnjane: Борић-Брешковић 1988: 89-96; Brežane: Вулић 1905: 92-93; Bujkovac: Борић-Брешковић и Митровић 2014: 87-134; Vlajića Brdo I: Арсенијевић 1997: 43-108; Vranje vicinity: Борић-Брешковић 1988: 8996; Popovac: Борић-Брешковић 1979: 39-54; Ćuprija vicinity: Борић-Брешковић 1983: 69-84; Izvore: Стаменковић и Самарџић 2013: 163-181; Vrkašice: Орлов 1970: 153161; Sremska Mitrovica: Орлов 1972: 153-161. 


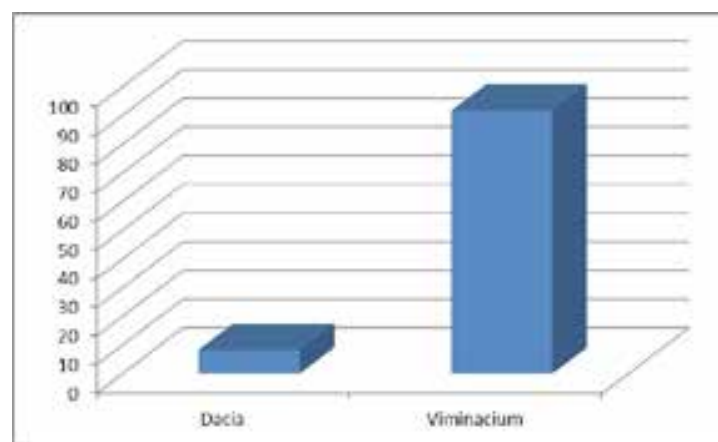

Graph 1 - Distribution of coins from the mints in Dacia and Viminacium in the area of today's Serbia

Unlike the finds of coins discovered during archaeological research and those from coin hoards, the presence of a certain type of coins in systematic museum collections does not provide equally reliable data on monetary circulation. In such cases, those are usually coins which came to museums from older private collections, and, therefore, their finding location is questionable. Nevertheless, in publishing certain museum collections, researchers have often stressed that those previous owners used to collect coins in given areas. ${ }^{9}$ Taken with a certain amount of caution, data from museum collections regarding the presence of provincial coins from Viminacium and Dacia certainly contribute to creating an image on the monetary circulation in Moesia Superior. Thus the numismatic cabinet of the National Museum in Belgrade contains 4770 examples of issues from Viminacium and only 105 from the mint in Dacia (Borić-Brešković, Vojvoda 2018: 79; Vojvoda, Crnobrnja in print). At the Belgrade City Museum, this ratio is 1700 examples from Viminacium to 183 examples from Dacian issues (Борић-Брешковић 1976; Borić-Brešković, Vojvoda 2018: 79; Црнобрња 1993); at the National Museum in Požarevac, it is 1335 to 34 (Borić-Brešković, Vojvoda 2018: 80; Бенџаревић, Бранковић 2016: 143-167); at the National Museum in Šabac, it is 59 to 4 (Борић-Брешковић,

9 For example, coins from the numismatic collection of the National Museum in Požarevac are mostly linked to Viminacium and its surroundings; cf. Бенџаревић и Бранковић 2016: 144, ref. 8, 150, ref. 46; Војвода и Бранковић 2016: 104; Borić-Brešković and Vojvoda 2018: 78, ref. 12 .
Петровић 2012: 135, ref. 1; Vojvoda, Crnobrnja in print) ${ }^{10}$ In total, finds from archaeological excavations, from hoards, and parts of previous private collections which are in several museums in Serbia today, provide us with 8072 examples of issues from the mint in Viminacium and 416 coins from the mint in Dacia (Graph 1).

Aside from production itself, other differences have also been noted in the work of the two provincial mints. The mint of Viminacium stands out in regard to the one from Dacia due to its considerably wider circulation area. After Moesia Superior, coinage from the mint of Viminacium is most numerous in Pannonia Inferior, followed by Dalmatia, Pannonia Superior and Dacia, with a smaller number of its issues even registered in Italy itself (Regio X, Venetia et Histria), in Noricum, then in Thrace and Moesia Inferior, as well as in barbaricum (part of the barbaricum in Banat), Ukraine, Belorussia, Poland, Germany, Slovakia (Borić-Brešković, Vojvoda 2018: 81-89, Graph 3, Map 1-2). Issues from the mint of Dacia had a different role in the circulation within the province of origin and in the area of Moesia Superior and both Pannonias, where they also occur, but on a considerably lower scale than in Dacia itself. Also, the influx of coins from the mint of Dacia was almost identical in Moesia Superior and both Pannonias (Găzdac and Alföldy-Găzdac 2008: 146, Fig. 4; Vojvoda and Crnobrnja in print, Graph 6).

A comparative analysis of monetary finds from these two mints on the territory of Moesia Superior and Dacia yielded the results shown in the following charts (Graph 2 and 3):

If we observe the ratios in Moesia Superior (Graph 2), we can note that the mint from Viminacium had an increase from the second to the fourth year of minting (AN II - IV VIM or 240/241-242/243), a decrease in the fifth year (AN $\mathrm{V}$ or 243-244), and a relatively uniform influx until the end of the ninth year. The opening of the mint in Dacia and the first two years of its minting

10 The mentioned examples from both mints come from the site of Banovo Polje. 


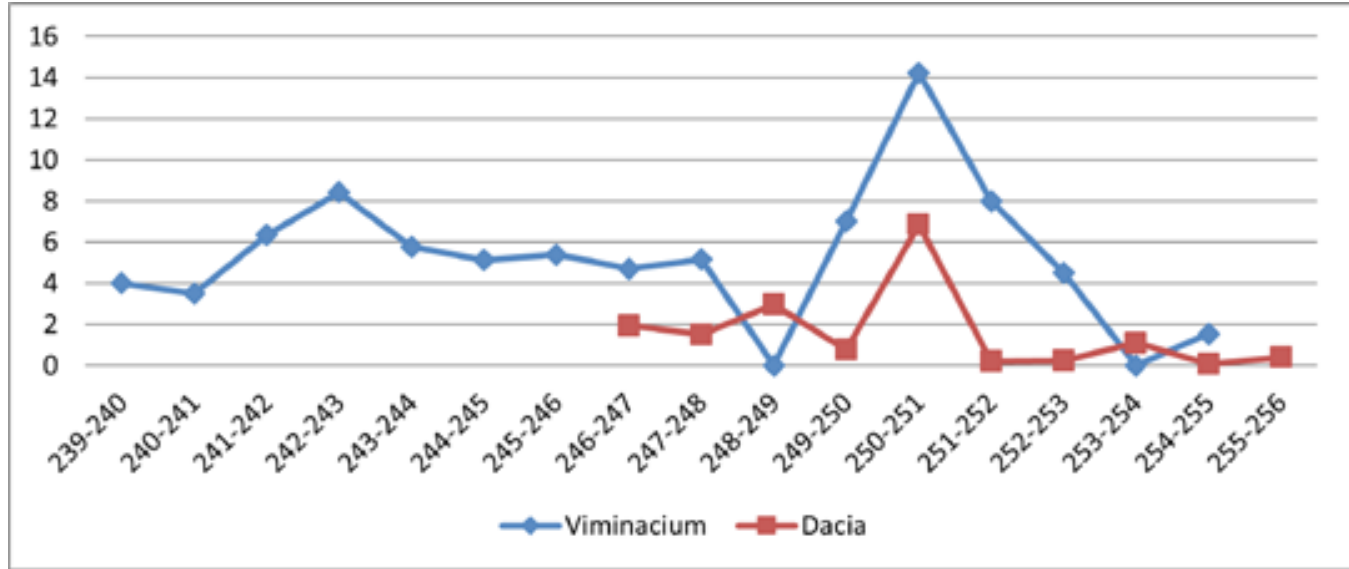

Graph 2 - Presence of provincial coinage from mints in Viminacium and Dacia in Moesia Superior, according to the minting year (AN I-XVI VIM and AN I-X DAC).

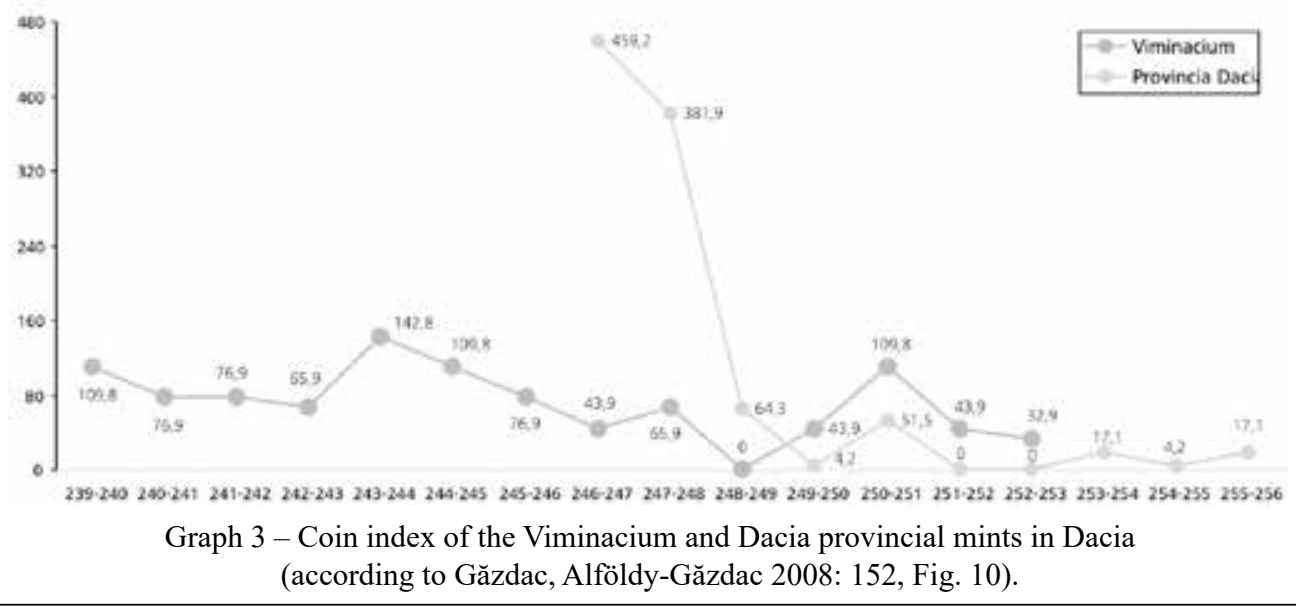

(AN I - II DAC or 246/247-247/248) left traces in the circulation in Moesia Superior, though certainly on a smaller scale than issues from the mint of Viminacium. The coinage from the first two years of the mint in Dacia was present in an almost identical percentage in Moesia Superior (AN I-II or 246/247-247/248). The first interruption of the operation of the mint from Viminacium (AN X VIM or 248/249) was followed by a certain increase in parallel Dacian issues from the third year (AN III DAC). As we have already mentioned, this was linked to the usurpation by Pacatianus, who used the mint of Viminacium for minting antoniniani at that time. ${ }^{11}$ According to M. Vasić, the mint of Dacia was also not active for several months, from the beginning of its fourth year (July/August 249) up to the moment that the Senate acknowledged

11 Cf. supra ref. 1.
Trajan Decius (October 249) (Vasić 2012: 15). In any case, the mint of Viminacium noted a considerable increase with Trajan Decius coming to power, from 249/250 (AN XI VIM), and achieved its peak of production in 250/251 (AN XII VIM). In parallel to the twelfth year of the Viminacium mint, ran the fifth year of the Dacian mint (AN $\mathrm{V}$ DAC), which also reached its highest influx in Moesia Superior. Events which caused the exceptional production of both mints were linked to the intrusion of Goths in Moesia Inferior and Thrace, the sojourn of Decius in the Balkans and his passing through Viminacium (Vasić 2012: 17).

The mint of Viminacium then noted a decrease in the following two years (AN XIII-XIV VIM), while the Dacian issues almost died away during its sixth and seventh year of minting (AN VI-VII DAC or 251/252-252/253). After a second inter- 
ruption in operation during the fifteenth year (AN XV VIM or 253/254), the mint of Viminacium operated for just one more year (AN XVI VIM or 254/255), and on a very small scale, after which it was closed. Graph 2 clearly shows that both mints reached their production peak in 250/251, while minting issues of Trajan Decius, Trebonianus Gallus and members of their families.

The picture is somewhat different when it comes to issues from the mint of Dacia in its province of origin (Graph 3). This relates, most prominently, to the first two years of minting (AN I-II DAC or 246/247-247/248), with its production continuing merely to decrease and be almost identical to the one noted in Moesia Superior. This massive production in the mint of Dacia is probably linked to the increased concentration of troops in this province because of the invasion of Carpi (Găzdac and Alföldy-Găzdac 2008: 141, ref. 42). Furthermore, issues from the mint of Dacia represent $40 \%$ of all the coins of Philip I found in Dacia (Găzdac and Alföldy-Găzdac 2008: 141, ref. 41). Also, these monetary finds are concentrated almost solely in the southern parts of the province, which is another fact that supports the newly defined location of this provincial mint in Apulum, and not in Ulpia Traiana Sarmizegetusa, as was traditionally believed. Apulum was the seat of Legio XIII Gemina, and there were also western Carpathian areas rich in ores in its vicinity (Găzdac-Alfoldy and Găzdac 2005: 651; Găzdac and Găzdac-Alfoldy 2008: 145). As for the issues of the mint of Viminacium, the dynamics of their influx into Dacia, by year, is similar to the that in Moesia Superior, although its issues are more numerous than those from the Dacian mint, with the exception of the first two years of minting in Dacia.

The founding of the mint in Viminacium and another one later in Dacia represented an official manner of temporarily solving a problem in the functioning of the monetary system of the Empire. However, it would seem that the roles of those two newly founded mints in the Balkans were different. As shown by the comparative analyses of finds from these two mints from the area of the province of Dacia, the issues from Viminacium had the goal of a wider circulation range, while issues from the province of Dacia, it would seem, were minted solely for the needs of that particular province. Namely, the mint of Dacia had a high production, and exceeded the number of issues from Viminacium in Dacia itself only in 246-249, and afterwards, from the rule of Philip I up to the rule of Valerian I, the issues of Viminacium were more numerous (Găzdac 2008: 275, 277, Fig. 9; Găzdac and Alföldy-Găzdac 2008: 152, Fig. 10; Borić-Brešković, Vojvoda 2018: 84). The production of both mints from the Balkans, that from Dacia and that from Viminacium, represented a manner of dealing with the monetary crisis in the middle of the 3rd century and providing the necessary money for the army.

\section{BIBLIOGRAPHY}

\section{Арсенијевић, М. 1997}

М. Арсенијевић, Остава римског новца са Влајића Брда из Смедеревске Паланке, Нумизматичар 20: 43-108.

(Arsenijević, M. 1997

Ostava rimskog novca sa Vlajića Brda iz Smederevske Palanke, Numizmatičar 20: 43-108).

\section{Бенџаревић, Т. и Бранковић, Т. 2016}

Т. Бенџаревић и Т. Бранковић, Новац провинције Дакије из колекције Народног музеја у Пожаревцу, Нумизматичар 34: 143-167.

(Bendžarević, T. i Branković, T. 2016

Novac provincije Dakije iz kolekcije Narodnog muzeja u Požarevcu, Numizmatičar 34: 143-167).

\section{Борић-Брешковић, Б. 1976}

Новаи колоније Виминацијума у збирии Светозара Ст. Душанића, Београд: Музеј града Београда. (Borić-Brešković, B. 1976

Novac kolinije Viminacijuma u zbirci Svetozara St. Dušanića, Beograd: Muzej grada Beograda). 


\section{Борић-Брешковић, Б. 1979}

Један мањи налаз римског новца из Поповца, Зборник Народног музеја Београд IX-X: 39-54. (Borić-Brešković, B. 1979

Jedan manji nalaz rimskog novca iz Popovca, Zbornik Narodnog muzeja Beograd IX-X: 39-54).

\section{Борић-Брешковић, Б. 1983}

Налаз бакарног римског новца из околине һyприје, Зборник Народног музеја Београд XI-1: 69-84.

(Borić-Brešković, B. 1983

Nalaz bakarnog rimskog novca iz okoline Ćupirje, Zbornik Narodnog muzeja Beograd XI-1: 69-84).

\section{Борић-Брешковић, Б. 1988}

Две оставе бакарног римског новца Виминацијума и Дакије, Зборник Народног музеја Београд XIII-1: 89-101.

(Borić-Brešković, B. 1988

Dve ostave bakarnog rimskog novca Viminacijuma i Dakije, Zbornik Narodnog muzeja Beograd XIII-1: 89-101).

Борић-Брешковић, В. и Митровић, G. 2014 Остава бронзаног новца Виминацијума и провинције Дакије из села Бујковац код Врањске Бање, Нумизматичар 32: 87-134.

(Borić-Brešković, B. i Mitrović, G. 2014

Ostava bronzanog novca Viminacijuma i provincije Dakije iz sela Bujkovac kod Vranjske Banje, Numizmatičar 32: 87-134).

\section{Borić-Brešković, B. and Vojvoda, M. 2018}

Circulation of Provincial Coins of the Viminacium Colony, In: VIVERE MILITARE EST, From Populus to Emperors - Living in the Frontier, Vol. II, S. Golubović, N. Mrđić (eds.), Belgrade: Institute of Archaeology: 73-100.

Црнобрња, Н. 1993

Новац провинцчије Дакије у збиричи Светозара Cm. Душанића, Београд: Музеј града Београда. (Crnobrnja, N. 1993
Novac provincije Dakije u zbirci Svetozara St. Dušanića, Beograd: Muzej grada Beograda).

\section{Dušanić, S. 1976}

The Era of Viminacium, u: Kovanje i kovnice antičkog i srednjovekovnog novca, V. Kondić (ed.), Beograd: Narodni muzej: 53-57.

Fitz, J. 1978

Der Geldumlauf der römischen Provinzen im Donaugebiet Mitte des 3. Jahruhunderts, Teil 1, Bonn-Budapest: Veriag \& Kiadó.

\section{Găzdac, C. 2008}

Aspects of coin circulation in Roman Dacia, in: Roman Coins outside the Empire, Ways and Phases, Contexts and Functions, Collection Moneta 82, Wetteren: Moneta: 269-294.

\section{Găzdac-Alföldy, Á. and Găzdac, C. 2005}

The role of coinage „Provincia Dacia“ in the coin supply at the Lower Danube region (3rd c. AD), in: Proceedings of the XIIIth International Numismatic Congress, held in Madrid, Spain, September 2003, Madrid: Ministerio de Cultura: 651-661.

\section{Găzdac-Alföldy, Á. and Găzdac, C. 2008}

The Management of a Monetary Crisis? The »P M S COL VIM « and »PROVINCIA DACIA« coinages in the Roman monetary policy of the 3rd century AD, NZ Bd. 116/117: 135-172.

\section{Kondić, V. 1969}

Beogradski nalaz denara i antoninijana, Beograd: Muzej grada Beograda.

\section{Орлов, Г. 1970}

Римски новац из Сремске Митровице нађен 1963. године, Старинар XIX (1968), 1970: 239250.

(Orlov, G. 1970

Rimski novac iz Sremske Mitrovice nađen 1963. godine, Starinar XIX (1968), 1970: 239-250. 


\section{Орлов, Г. 1972}

Налаз римског новца колоније Виминацијум и провинције Дакије на локалитету Вркашице код Сремске Митровице, Старинар XXI (1970) 1972: 153-161.

(Orlov, G. 1972

Nalaz rimskog novca kolonije Viminacijum i provincije Dakije na lokalitetu Vrkašice kod Sremske Mitrovice, Starinar XXI (1970) 1972: 153-161).

\section{Pegan, E. M. 1984}

Tiberius Claudius Marinus Pacatianus (nepublikovana doktorska disertacija), Ljubljana: Univerza Edvarda Kardelja v Ljubljani.

Стаменковић, С. и Самарџић, Г. 2013

Остава римског новца из средине III вијека са локалитета Изворе код Косовске Митровице, Зборник радова Филозофског факултета у Приштини XLIII (2): 163-181.

(Stamenković, S. i Samardžić, G. 2013

Ostava rimskog novca iz sredine III vijeka sa lokaliteta Izvore kod Kosovske Mitrovice, Zbornik radova Filozofskog fakulteta u Prištini XLIII (2): 163-181).

\section{Vasić, M. R. 2005}

Ostava denara i antoninijana iz Donjeg Crniljeva IA Hoard of Denarii and antoniniani from Donje Crniljevo, Belgrade: Institute of Archaeology.

Vasić, M. R. 2012

Imperial and Colonial Mint in Viminacium during the Reign of Trajan Decius (249-251 AD), Belgrade: National Museum Belgrade.

\section{Војвода, М. 2013}

Новац битинијске ковнице Никеје са виминацијумске некрополе Више Гробаља, Нумизматичар 31: 155-196.

(Vojvoda, M. 2013

Novac bitinijske kovnice Nikeje sa viminacijumske nekropole Više Grobalja, Numizmatičar 31: 155-196).

\section{Војвода, М. и Бранковић Т. 2016}

Новац битинијске ковнице Никеје из римске нумизматичке збирке Народног музеја у Пожаревцу, Нумизматичар 34: 103-142.

(Vojvoda, M. i Branković, T. 2016

Novac bitinijske kovnice Nikeje iz rimske numizmatičke zbirke Narodnog muzeja u Požarevcu, Numizmatičar 34: 103-142).

\section{Vojvoda, M. and Crnobrnja, A. 2018}

Circulation of the coins of Bithinian mint of Nicaea in Moesia Superior, in: Proceedings of the International Numismatic Symposium »Circulation of Antique Coins in Southeastern Europe«, Viminacium 2017, V. Ivanišević, B. Borić-Brešković, M. Vojvoda (eds.), Belgrade: Institute of Archaeology: 131-141.

Vojvoda M. and Crnobrnja A. N. Circulation of provincial coins „Provincia Dacia“ at the territory of present-day Serbia, Proceedings of the XXIIII Limes Congress (in print).

\section{Војвода, М. и Јесретић М. 2012}

Новац битинијске ковнице Никеје из Музеја Срема у Сремској Митровици, Нумизмтатичар 30: 114-132.

(Vojvoda, M. i Jesretić, M. 2012

Novac bitinijske kovnice Nikeje iz Muzeja Srema u Sremskoj Mitrovici, Numizmatičar 30: 114-132).

\section{Vojvoda, M. i Mrđić, N. 2015}

Nalazi novca sa viminacijumske nekropole Više grobalja i njihova uloga u pogrebnom ritualu / Coin finds from the Viminacium necropolis of Više grobalja and their role in funerary ritual, Belgrade: Institute of Archaeology.

\section{Vojvoda, M. i Mrđić, N. 2017}

Nalazi novca sa viminacijumske nekropole Pećine i njihova uloga u pogrebnom ritualu /Coin finds from the Viminacium necropolis of Pećine and their role in funerary ritual, Belgrade: Institute of Archaeology. 
Војвода, М. и Петровић, С. 2011

Новац битинијске ковнице Никеје из Бановог Поља у Мачви, Нумизматичар 29: 283-308. (Vojvoda, M. i Petrović, S. 2011

Novac bitinijske kovnice Nikeje iz Banovog Polja u Mačvi, Numizmatičar 29: 283-308).

Вулић, Н. 1905

Антички споменици у Србији, Споменик CКА 42: 79-99.

(Vulić, N. 1905

Antički spomenici u Srbiji, Spomenik SKA 42: 79-99).

\section{REZIME}

ODNOS ZASTUPLJENOSTI EMISIJA KOVNICE

VIMINACIJUM I DAKIJA: PRIMER VIMINACIJUMSKIH JUŽNIH NEKROPOLA

\section{KLJUČNE REČI: RIMSKO CARSTVO, PROVIN- CIJALNE KOVNICE, VIMINACIUM, DACIA.}

Nedostatak imperijalnog bronzanog novca $u$ opticaju podunavskih i balkanskih provincija početkom 3. v. bio je posebno izražen i verovatno je predstavljao glavni razlog za otvaranje kovnice provincijalnog novca u Viminacijumu 239. g., a potom i u Dakiji 246.g. Kovnica provincijalnog novca u Viminacijumu otvorena je oktobra 239. godine što je bio i početak računanja provincijalne ere (AN I - AN XVI). Radila je 16 godina, od 239/240. godine do 254/255. godine sa dva prekida tokom 248/249 (AN X) i 253/254 (AN XV). Kovnica provincijalnog novca u Dakiji emitovala je novac deset godina uz oznaku lokalne ere od AN I - X (246/247-254/256).

$\mathrm{Za}$ analizu monetarne cirkulacije na teritoriji Gornje Mezije u periodu 192-238 AD, odnosno periodu koje prethodi otvaranju kovnice provincijalnog novca u Viminacijumu, a potom i kovnice u Dakiji, dragoceni su podaci o nalazima novca sa viminacijumskih južnih nekropola. Nalazi novca provincije Dakije, srazmerno daleko manjoj pro- dukciji u odnosu na kovnicu Viminacijum, imali su izvesnu ulogu u monetarnoj cirkulaciji na prostoru Gornje Mezije. Tako sa viminacijumskih južnih nekropola potiče 155 primeraka novca kovnice Viminacijum $(93,40 \%)$ i 11 iz kovnice Dakija (6,60\%). Izvestan broj dačkih izdanja potiče i iz 10 ostava novca, u kojima je zabeležen sličan odnos zastupljenosti viminacijumske u odnosu na dačku kovnicu. Ukupno uzevši, nalazi sa arheoloških istraživanja, iz ostava, kao i delovi ranijih privatnih kolekcija koje se danas nalaze u više muzeja u Srbiji, iznose 8072 primeraka emisija viminacijumske kovinice i 416 moneta kovnice Dakija (Grafikon 1).

Osim same produkcije, do sada su uočene i druge razlike u radu dve provincijalne kovnice. Viminacijumska se ističe u odnosu na kovnicu Dakija, izuzetno širim arealom cirkulacije. Kako su pokazale komparativne analize monetarnih nalaza ove dve kovnice na području provincije Dakije, emisije Viminacijuma imale su za cilj širu cirkulaciju, dok su emisije provincije Dakije izgleda kovane samo za potrebe matične provincije. Produkcija obe balkanske kovnice, u Dakiji i Viminacijumu, predstavljala je način upravljanja monetarnom krizom iz sredine 3. veka i snabdevanja vojske neophodnim novcem.

Arheologija i prirodne nauke (Archaeology and Science) is an Open Access Journal. All articles can be downloaded free of charge and used in accordance with the licence Creative Commons - Attribution-NonCommercial-NoDerivs 3.0 Serbia (https://creativecommons.org/licenses/ by-nc-nd/3.0/rs/.

Časopis Arheologija i prirodne nauke je dostupan u režimu otvorenog pristupa. Članci objavljeni u časopisu mogu se besplatno preuzeti sa sajta i koristiti u skladu sa licencom Creative Commons - Autorstvo-Nekomercijalno-Bez prerada 3.0 Srbija (https://creativecommons.org/ licenses/by-nc-nd/3.0/rs/. 